\title{
Chemical Compositions of Selected Browse Species Used as Goat Feed in Bena-Tsemay district of South Omo, South-Western Ethiopia
}

\section{Denbela Hidosa* and Bizuayehu Ayele}

Livestock Research Directorate, Jinka Agricultural Research Center, Jinka, Ethiopia

*Corresponding Author: Denbela Hidosa, Livestock Research Directorate, Jinka Agricultural Research Center, Jinka, Ethiopia.

Received: December 31, 2021; Published: January 04, 2022

\begin{abstract}
The browse species are an important source of nutrients for goats in arid range-land. However, the chemical compositions of browse species used as goat feed in Bena-Tsemay district have not studied and documented for future long-term utilization which target to properly balance their inclusion levels in animal diets. Thus, this study was conducted to assess chemical compositions of selected browse species browsed by goats. The leaves of fourteen browse species samples were collected from range-land and analyzed for chemical compositions in completely randomized block design by using the Generalized Linear Model (GLM) procedures of SAS. The higher ( $\mathrm{p}<0.05)$ crude protein (CP) $(198 \mathrm{~g} / \mathrm{kg}$, DM) was observed in A. marina leaves, while the lower CP levels (125g/kg, DM) and (126g/kg, DM) were observed in A. tortilis and G. tenax leaves, respectively. The S. birrea leaves had higher $(\mathrm{p}<0.05)$ estimated dry matter intake $(94.05 \mathrm{~g} / \mathrm{kg}, \mathrm{DM})$, while it was lower $(58.57 \mathrm{~g} / \mathrm{kg}$, DM) for A. tortilis leaves. However, the digestible dry matter (DDM), total digestible nutrients (TDN), relative feed value (RFV) and metablisable energy (ME) values were similar $(\mathrm{p}<0.05)$ among the all studied browse plant species. Based on result from this study, it can be concluded that all studied browse plants had high-quality-protein to supplement poor-quality-roughage feeds for enhanced livestock production. Also, it is suggested that future research will consider the supplementation effects of browse plant on animal performances (meat, milk and growth rate).
\end{abstract}

Keywords: Crude protein; Digestible dry matter; Dry matter intake; Relative feed value; Metabolizable energy

\section{Introduction}

Ethiopia has an approximately 38.94 million goat's population [1] which have been contributing the vigorous role over providing foods (milk and meat) and immediate cash incomes for smallholder rural communities [2]. Despite of vigorous role to rural communities, the outputs from goat production system in Bena-Tsemay district is generally quite poor due to the deficits in quantity and poor quality of goat feeds $[3,4]$. In this district, the goat production systems are seldom allowed to express their genetic potentials due to poor feeding and husbandry practices. It is obvious that poorly fed goat give low output, late age of onset of puberty and low conception rates, and take too long to reach optimum slaughter and marketable weights. The proper goat feeding, health care and overall management of goats is a pre-requisite for realizing the genetic potential of breed. In Bena-Tsemay district, about $80 \%$ of the goats feeds are derived from range-lands (pasture grasses, legumes, fodder trees and shrubs) [3]. The browse species are important feed sources for goat in arid-niches where herbaceous forage productivity is low, due to their high potential to survive in severe arid niches [5]. The browse plant species are often have a higher crude-protein and mineral contents in addition to higher dry matter degradability than associated grasses, particularly during the dry season as an important attendant advantage due to a reduced dependence on purchased protein supplements [6-8]. In addition, goat keepers in the various range-lands have been known for utilizing the browser species as source feeds for goat (protein, vitamins, and minerals) and traditional medicine for healing and treating diseases and par- 
asites of goats [9-12]. Also, the browse species known for prevent desertification over mitigating the effects of droughts, allowing soil fixation and restoring the degraded range-land [13]. Thus, understanding qualities and nutritive values of browse plant species is a quite an indispensable for the designing the long-term utilization of browse species which will be targeted to properly balance their levels in goat diets. However, with above merits, the browse plant species used as goat feeds were identified and well documented for Bena-tsemay district [4], but not their chemical composition have not assessed for future use in goat diet. Therefore, this study was conducted to assess chemical composition of selected browse plant species used as goat feed in Bena-Tsemay district for possible utilization as protein supplement.

\section{Material and Methods \\ Description of Study Area}

The study was conducted in MorigolaKebele of Bena-Tseamy district from June to July, 2020. The study rangeland site had lied between $5^{\circ} 01^{\prime}$ and $5^{\circ} 73^{\prime}$ North latitude and $36^{\circ} 38^{\prime}$ and $37^{\circ} 07^{\prime}$ East longitude in the Bena-Tsemay. An area is characterized by semi-arid and arid climatic condition, with mean annual rainfall averaged from 350-838mm with bimodal distribution and has an ambient temperature ranged from $26-35^{\circ} \mathrm{C}$ [14]. The vegetation of the study district is dominated by varying densities of Acacia, Grewia, and Solanum woody species $[4,15]$. The dominant type of land-use is agro-pastoralism [3, 4] and total land is used for grazing and browsing by cattle and goats, respectively [15]. Rain-fed agriculture is practiced and sorghum, maize, millet, bean, wheat, barley, and vegetables were the major crops grown by agro-pastoralists $[15,16]$.

\section{Sample Collection and Processing}

The leaves of fourteen major browse species used as goat feed were collected from MorigolaKebele in consultation with the most experienced agro-pastoralists and experts based on their high preference to goats in three replicates per each plant during the $50 \%$ flowering period and catalogued by local plant names. Upon return from the field, scientific names of certain browse plant species were nominated by using Ethiopia Flora identification Book [17], but those which were difficult to recognize scientific names in the field were registered with local name and transported to Adami Tule Agricultural Center by pressed with plant press and identified by experienced botanist. The leaves samples of browse species in three replicates per plant were processed by handpicking and air-dried at room temperature at Feed and Nutrition laboratory of Jinak Agricultural Research Center.

\section{Chemical Composition Analysis}

The chemical compositions of samples of browse plant were analyzed in Animal Science Laboratory at DebreBirhan Agricultural Research Center. Three leave samples of each selected browse species were allowed to oven dried in oven set at a temperature of $65^{\circ} \mathrm{C}$ for 48 hours and ground in hammer mill to pass a $1 \mathrm{~mm}$ sieve screen for chemical analysis [18]. The crude protein (CP) and ash contents were analyzed according to the methods of [18]. The neutral detergent fiber (NDF) content was calculated according to the procedure of [19], while the acid detergent fiber (ADF) value was analyzed by the method described by [20]. The estimated relative feed value (RFV) was calculated from the estimated digestible dry matter (DDM) by using calculation described by [21]. The procedure of [22] was used to estimate dry matter intake (DMI) value of browse plant with following calculations: DDM = Digestible Dry Matter $=88.9-(0.779 \times$ \% ADF $)$, DMI = Dry Matter Intake (\% of BW $)=120 /(\%$ NDF $)$, RFV = (DDM x DMI)/1.29. The estimated digestible dry matter (DDM) value was used to estimate digestible energy (DE, MJ $/ \mathrm{kg})$ using the equation reported by [23]; DE $(\mathrm{MJ} / \mathrm{kg})=0.27+$ 0.0428 (DDM\%). Then, DE value was converted to ME using the formula reported by [24]; ME (MJ $/ \mathrm{kg} \mathrm{DM)} \mathrm{=0.821 \times DE} \mathrm{(MJ} / \mathrm{kg} \mathrm{DM})$. The body weight used to estimate daily dry matter intake is equivalent to an estimated livestock unit metabolic weight of $250 \mathrm{~kg}$ at $2.5 \%$ daily dry matter intake suggested for tropical condition [25].

\section{Statistical Analysis}

The chemical compositions of browse plants were subjected to analysis of variances (ANOVA) using the General Linear Model (GLM) 
procedure of SAS [26] in completely randomized block design. The significant differences among the means of studied browse plants were declared at $\mathrm{p}<0.05$ probability level and means were separated using Tukey test with following model:

Yijk $=\mu+$ BSi + eijk, where; yijk $=$ all dependent variables; $\mu=$ overall mean; BSi $=$ the effect of browse species and eijk $=$ random error.

\section{Results and Discussion}

\section{Chemical Composition}

Chemical compositions of fourteen browse plants used as goat feed in Bena-Tsemay district are presented in Table1. The I. spicata leaves had higher $(\mathrm{p}<0.05)$ ash content than $A$ senegalensis, C. molle, G. villosa, G. tenax, and S.birrea leaves, but ash content wascomparable (p>0.05) to A. albida, A. tortilis, A. nilotica, A. seyal, B. discolour, B. aegyptila, A. manna and R. natalensis leaves. The A.marina leaves contained higher $(\mathrm{p}<0.05) \mathrm{CP}$ concentration than A. nilotica, A.seyal, A.tortilis, G. villosa and G. tenax, while CP concentration was comparable ( $\mathrm{p}>0.05$ ) to $S$. birrea, B. aegyptila, I. spicata A senegalensis, A. albida and B. discolour leaves. The A. tortilis leaves had higher $(\mathrm{p}<0.05)$ NDF content than $S$. birrea leaves, but the NDF content was comparable ( $p>0.05)$ to others browse species, while ADF content was similar ( $p>0.05$ ) among the leaves of all browse plants, but higher $(\mathrm{p}>0.05)$ ADF value was noted for $G$. villosa and lower was for $A$. nilotica leaves. The higher CP concentration for A. marina leaves from this study is might be due to either genotypic potential of tree to fix atmospheric nitrogen and accumulate high content of nutrients which is required for optimum growth and accumulation of more nitrogen in their leaves. The CP concentration of A. marina leaves in this study was higher than reported value of $(133 \mathrm{~g} / \mathrm{kg}, \mathrm{DM}) \mathrm{by}$ [27], (110.4g/kg, DM) by [28] and (151.4g/kg, DM) by [29]. The crude protein of $A$. seyal leaves in this study was lower than reported value of $(169.6 \mathrm{~g} / \mathrm{kg}$, DM) by [30] from Ethiopia. The CP concentration of A. albida leaves in this study was lower than reported values of $(201.80 \mathrm{~g} / \mathrm{kg}$, DM) and $(197 \mathrm{~g} / \mathrm{kg}$, DM) reported by [30] and [31], respectively. The CP concentrations of $A$. toritlis, A. nilotica and $A$. senegalensis leaves from this study were lower than reported CP concentrations of $(152.9 \mathrm{~g} / \mathrm{kg}, 157.6 \mathrm{~g} / \mathrm{kg}, 159.3 \mathrm{~g} / \mathrm{kg}$, DM) by [12], respectively but CP concentration for B. disclour in this study was higher than reported value of $(116.4 \mathrm{~g} / \mathrm{kg}$, DM) by same author. The CP level for C. molle from this study was lower than reported value of $(160 \mathrm{~g} / \mathrm{kg}$, DM) by [32], but CP concentration for G. tenax was higher than value of $(93 \mathrm{~g} / \mathrm{kg}$, DM) by the same author. The CP concentration from this study for I. spicata was lower than reported value of $(228 \mathrm{~g} / \mathrm{kg}, \mathrm{DM})$ by [33] and for B. aegyptila was lower reported value of $(172 \mathrm{~g} / \mathrm{kg}$, DM) by [32] but the crude protein concentration of S. birrea leaves was higher than reported value of $(157 \mathrm{~g} / \mathrm{kg}$, DM) by the same author. The protein is the most critical nutrient in animal diets which is serving as the structural component of muscle and tissues, source of hormones, enzymes and hemoglobin [34, 35]. The animals are needed diet which has high-quality-protein to acquire desire outputs. The ruminant herbivores will transform the crude protein in the diet into ammonia by microbial digestion, and this ammonia is used as source of nitrogen for rumen microbes to synthesis microbial-protein which will used by host-animal [36]. Generally, the crude protein concentration from present study $(124 \mathrm{~g} / \mathrm{kg}-198 \mathrm{~g} / \mathrm{kg}$, DM) for all browse species were higher than the minimum required crude protein levels $(70-80 \mathrm{~g} / \mathrm{kg}$, DM) for normal microbial digestion take place in rumen of ruminant herbivores [37-39]. Also, the crude protein levels obtained from this study for the all browse species were above the minimum crude protein levels which needs ruminant animals for proper growth $(113 \mathrm{~g} /$ $\mathrm{kg}, \mathrm{DM})$ and lactation $(120 \mathrm{~g} / \mathrm{kg}, \mathrm{DM})[40,41]$. In addition, the livestock feeds were categorized into three categories based on CP and total digestible nutrient (TDN) contents, as low-quality-feeds (CP $<4 \%$ and TDN $<40 \%$ ), medium-quality-feeds (CP 5-10\% and TDN 40-50\%) and high-quality-feeds (CP> 10\%, and TDN> 50\%) [42]. Based on this classification, all browse species studied in this study had categorized as high-quality-feeds which have potential to use as protein-supplements to the livestock fed on poor-quality-diets. The recognizing the cell wall contents of feed stuff is an important steps in livestock feed preparation due to feeds with high contents of cell walls are greatly influenced both feed intake and digestibility by animals [38]. The neutral detergent fiber (NDF) value of feed is greatly correlated to feed intake, while acid detergent fiber (ADF) content is related to the digestibility potential of feed [36]. The higher NDF content of $A$. toritlis leaves from this study is might be due to harvested leaves samples were at advanced age which had contained more stem parts which is responsible to higher NDF content. The NDF content of $A$. tortilis leaves in this study was higher than reported value of (338.4g/kg, DM) by [12], but lower than reported value of $(506 \mathrm{~g} / \mathrm{kg}$, DM) by [43]. The NDF content of $A$. seyal and A. albida leaves in this study were lower than reported values of $(684.43 \mathrm{~g} / \mathrm{kg}, \mathrm{DM})$ and $(512.8 \mathrm{~g} / \mathrm{kg}$, DM) by [30], respectively. The

Citation: Denbela Hidosa and Bizuayehu Ayele. "Chemical Compositions of Selected Browse Species Used as Goat Feed in Bena-Tsemay district of South Omo, South-Western Ethiopia”. Medicon Microbiology 1.1 (2022): 05-12. 
NDF values of $A$. toritlis and $A$. nilotica leaves from this study were higher than reported value of (3384g/kg, $342 \mathrm{~g} / \mathrm{kg}$, DM), respectively by [12], but NDF value was lower than reported values of $(630 \mathrm{~g} / \mathrm{kg}, \mathrm{DM})$ and $(635.2 \mathrm{~g} / \mathrm{kg}, \mathrm{DM})$, respectively for $A$. senegalensis and $B$. disclour by the same author. The NDF values for C. molle and G. tenax in this study was lower than reported values of (524.4g/kg, DM) and (870g/kg, DM) by [32], respectively. The NDF content in this study for I. spicata was higher than reported value of (363g/kg, DM) by [33] and NDF value for B. aegyptila was lower reported value of (319g/kg, DM) by [32], but the NDF content for $S$. birrea leaves was higher than reported value of $(148 \mathrm{~g} / \mathrm{kg}$, DM) by the same author. Based on result of NDF content from this study, all leaves of tested browse plants have NDF content which is below the recommended levels $(600-650 \mathrm{~g} / \mathrm{kg}$, DM) which impairs the dry-matter intake in ruminant animal [19]. Moreover, the ADF values from this study are ranged from 233 to $451 \mathrm{~g} / \mathrm{kg}$ DM, which falls within the acceptable range where browse substrates are expected to be digestible [44] and would not negatively influence feed digestibility.

\begin{tabular}{|c|c|c|c|c|c|c|}
\hline S/No & Scientific Name & $D M \%$ & Ash & $C P$ & $N D F$ & $A D F$ \\
\hline 1 & A. albida & 916.7 & $96^{\mathrm{ab}}$ & $159^{\text {abcde }}$ & $527^{\mathrm{ab}}$ & 385 \\
\hline 2 & A. tortilis & 910 & $104^{\mathrm{ab}}$ & $135^{\mathrm{de}}$ & $551^{\mathrm{a}}$ & 413 \\
\hline 3 & A. nilotica & 916.7 & $88^{\mathrm{ab}}$ & $126^{\mathrm{e}}$ & $441^{\mathrm{ab}}$ & 233 \\
\hline 4 & A. seyal & 910 & $101^{\mathrm{ab}}$ & $137^{\text {cde }}$ & $404^{\mathrm{ab}}$ & 324 \\
\hline 5 & B. discolor & 876.7 & $155.67^{\mathrm{a}}$ & $191^{\mathrm{ab}}$ & $418^{\mathrm{ab}}$ & 302 \\
\hline 6 & C. molle & 900 & $57^{\mathrm{b}}$ & $140^{\text {cde }}$ & $462^{\mathrm{ab}}$ & 385 \\
\hline 7 & A. senegalensis & 906.7 & $67^{\mathrm{b}}$ & $151^{\text {abcde }}$ & $494^{\mathrm{ab}}$ & 400 \\
\hline 8 & G. villosa & 920 & $59^{b}$ & $129^{e}$ & $548^{\mathrm{a}}$ & 451 \\
\hline 9 & G. tenax & 903.3 & $54^{\mathrm{b}}$ & $125^{\mathrm{e}}$ & $442^{\mathrm{ab}}$ & 306 \\
\hline 10 & I. spicata & 913.3 & $156^{\mathrm{a}}$ & $184^{\mathrm{abc}}$ & $427^{\mathrm{ab}}$ & 338 \\
\hline 11 & B. aegyptila & 910 & $117^{\mathrm{ab}}$ & $162^{\text {abcde }}$ & $496^{\mathrm{ab}}$ & 285 \\
\hline 12 & A. marina & 890 & $88^{\mathrm{ab}}$ & $198^{\mathrm{a}}$ & $467^{\mathrm{ab}}$ & 385 \\
\hline 13 & S. birrea & 893.3 & $54^{\mathrm{b}}$ & $182^{\mathrm{abcd}}$ & $347^{c}$ & 259 \\
\hline \multirow[t]{2}{*}{14} & R. natalensis & 920 & $94^{\mathrm{ab}}$ & $147^{\text {bcde }}$ & $500^{\mathrm{ab}}$ & 422 \\
\hline & SEM & 1.80 & 4.79 & 4 & 7.87 & 9.33 \\
\hline
\end{tabular}

Keynote: (Means along column with different letters for ashes, CP, NDF and ADF are significantly different at $\mathrm{p}<0.05$; DM\%, dry matter percent; $\mathrm{CP}$, crude protein; NDF, neutral detergent fiber; ADF, acid detergent fiber; SEM, standard error of mean).

Table 1: Chemical composition ( $\mathrm{g} / \mathrm{kg}$, DM) of selected browse plant used as goat in Bena-Tsemaydistrict of South Omo Zone, South-western, Ethiopia.

The estimated metabolizable energy (ME), digestible dry matter (DDM), Dry matter intake (DMI), total digestible nutrient (TDN) and relative feed value (RFV) of selected browse plants used as goat feed in Bena-Tsemay district are presented in Table 2. The result in this study revealed that $S$. birrea leaves had higher $(\mathrm{p}<0.05)$ estimated DMI than A. albida, A. tortilis, A. senegalensis, R. natalensis and G. villosa leaves, but DMI was comparable ( $>0.05$ ) to other browse plants. The estimated digestible dry matter (DDM) in this study was higher ( $\mathrm{p}>0.05$ ) for A. nilotica leaves followed by S. birrea leaves, but the DDM was lower for G. villosa leaves. The A. nilotica leaves had higher ( $p>0.05$ ) estimated total digestible nutrient (TDN) followed by $S$. birrea and G. tenax leaves, but TDN value was lower ( $>0.05$ ) for $G$. villosa leaves. The B. aegyptila leaves had higher ( $\mathrm{p}>0.05)$ estimated relative feed value (RFV) followed by $A$. tortilis and $A$. nilotica leaves, but RFV was lower for G. villosa leaves. The higher estimated dry matter intake (DMI) for $S$. birrea leaves in this study is due to lower NDF and ADF contents of leaves (Table 2). It is obvious that the feed that have higher NDF and ADF values, slows the rate of nutrient digestion process which have resulted in lower dry matter intake and allows animals to consume less forages [38]. However, animals fed on high-quality-forages are expected to quickly consume more due to high digestion and rate of passage [45]. Similar to 
result on estimated DMI from present study, [8] reported differences in estimated dry matter intake for five browse plants from Indonesia. The estimated dry matter intake obtained in this study (58.57- $94.05 \mathrm{~g} / \mathrm{kg}$, DM) is higher than reported value of (12.5g/kg, DM) for S. lancea leaves and (17.7g/kg, DM) for M. oleifera leaves by [8]. The higher estimated digestible dry matter (DDM) for A. nilotica and $S$. birrea leaves in this study is due to lower ADF content. The feeds with higher ADF contents have a higher indigestible fiber fraction (cellulose, lignin, silica) which is clues to lower digestibility of feeds [36, 42]. The estimated DDM in this study (636.24-707.47g/ $\mathrm{kg}$, DM) is higher than reported values ranged from $(270.4 \mathrm{~g} / \mathrm{kg}, \mathrm{DM})$ to $(366 \mathrm{~g} / \mathrm{kg}$, DM) by [8] for five browse plants, but DDM value was relatively within range of reported values $(677-748 \mathrm{~g} / \mathrm{kg}$, DM) by [46] for four Sevena browse species from Ghana. The similarity in estimated relative feed value (RFV) values from this study for browse plants is might be due to similarity in ADF contents among the tested browse plants. This is due the fact that, the RFV is estimated from the DMI and DDM of feeds, which is directly influenced by ADF content of feeds. Indeed, it was reported that feed with higher RFVs had lower NDF and ADF contents which indicates the higher forage quality [47-49]. The relative feed value obtained from this study for all browse species were within the recommended ranges which will be considered as quality feed ingredients for inclusion in ruminant ration (RFV >151) by [50]. The RFV obtained in this study were similar to reported values which ranged from $(496.5 \mathrm{~g} / \mathrm{kg}, \mathrm{DM})$ to $(921.6 \mathrm{~g} / \mathrm{kg}$, DM) by [8] for five browse plants, but it was higher than reported values (120.2-212.6g/kg, DM) by [46] for four Sevena browse species from Ghana.

\begin{tabular}{|c|c|c|c|c|c|c|}
\hline S/No & Scientific Name & $D D M(g / k g D M)$ & $D M I(g / k g D M)$ & $T D N(g / k g D M)$ & $R F V(g / k g D M)$ & $M E(M J / K g)$ \\
\hline 1 & A. albida & 589.09 & $64.52^{\mathrm{b}}$ & 534.47 & 717.66 & 0.20 \\
\hline 2 & A. tortilis & 567.27 & $58.57^{\mathrm{b}}$ & 513.43 & 751 & 0.20 \\
\hline 3 & A. nilotica & 707.47 & $73.27^{\mathrm{ab}}$ & 648.68 & 746.26 & 0.25 \\
\hline 4 & A. seyal & 636.34 & $79.84^{\mathrm{ab}}$ & 580.06 & 617.98 & 0.22 \\
\hline 5 & B. discolor & 653.48 & $78.45^{\mathrm{ab}}$ & 596.60 & 648.16 & 0.23 \\
\hline 6 & C. molle & 588.83 & $70.61^{\mathrm{ab}}$ & 534.22 & 652.30 & 0.21 \\
\hline 7 & A. senegalensis & 577.66 & $65.59^{\mathrm{b}}$ & 523.45 & 686.15 & 0.20 \\
\hline 8 & G. villosa & 537.41 & $58.85^{b}$ & 484.62 & 707.82 & 0.19 \\
\hline 9 & G. tenax & 667.24 & $75.61^{\mathrm{ab}}$ & 609.87 & 695.48 & 0.23 \\
\hline 10 & I. spicata & 625.70 & $75.57^{\mathrm{ab}}$ & 569.79 & 641.84 & 0.23 \\
\hline 11 & B. aegyptila & 650.11 & $65.35^{\mathrm{b}}$ & 593.34 & 777.97 & 0.23 \\
\hline 12 & A. marina & 585.32 & $68.93^{\mathrm{ab}}$ & 530.90 & 663.74 & 0.24 \\
\hline 13 & S. birrea & 686.98 & $94.05^{\mathrm{a}}$ & 628.91 & 570.79 & 0.24 \\
\hline \multirow[t]{2}{*}{14} & R. natalensis & 560.52 & $61.28^{\mathrm{b}}$ & 506.92 & 719.57 & 0.19 \\
\hline & SEM & 8.24 & 3.02 & 0.02 & 8.02 & 0.02 \\
\hline
\end{tabular}

Keynote: (Means along column with different letters $(a, b)$ for DDM, DMI, TDN, RFV and ME are significantly different at P<0.05; DDM, digestible dry matter; DMI, dry matter intake; TDN, total digestible nutrient; RFV, relative feed value; ME, metabolizable energy; MJ, mega joule; SEM= Standard error of mean)

Table 2: Digestible dry matter (DDM), Dry matter intake (DMI), total digestible nutrients (TDN), relative feed value (RFV) and metabolizable energy (ME) of selected browse species used as goat feed in Bena-Tsemay district of South Omo Zone, South-western Ethiopia.

\section{Conclusion}

The leaves of all browse which have been utilizing as goat feed in the study area had higher crude protein which is above the minimum required CP levels (70-80g/kg, DM) for normal microbial digestion and categorized as high-quality-forage classes. Thus, based on result from this study, it could be concluded that all browse plants evaluated in this study had higher crude protein and will be used as alternative protein source to supplement animals fed on poor-quality-roughage diets. The in-situ-future feeding trials to develop 
more informative confidence and put strong recommendation about studied browse plants.

\section{Acknowledgement}

This study was conducted funds from Regional Agricultural Growth Program II (AGPII). The authors extremely thankful the AGPII Coordination Office at Hawassa for fully supplies funds for this study. Also authors were grateful to acknowledge MorigolaKebele Developmental Agents and Agro-pastoralists who fully participation forage sample collection and local name identification. Finally, authors would like to acknowledge the experienced botanist MrBediruRoba from the Adami Tulu Agricultural Research Centre for assigned botanical names of browse species.

\section{References}

1. Central Statistical Agency (CSA) (2018/2019). Agricultural Sample Survey, Report on livestock and livestock characteristics (Private peasant holdings), volume II, Statistical Bulletin, 587.Addis Ababa, Ethiopia.

2. Zewdu A and Peacock C. "Improving Access to and Consumption of Animal Source Foods in Rural Households: The Experiences of a Women-Focused Goat Development Program in the Highlands of Ethiopia". Dairy Goat Project, FARM-Africa, Bloomsbury, London (2003).

3. Berhanu, Tekleyohannes., et al. "Availability of feed resources for goats in pastoral and agro-pastoral districts of south omo zone, ethiopia". International Journal of Research-Granthaalayah 5.3 (2017): 154-160.

4. DenbelaHidosa., et al. "Goat Feed Inventory and Feed Balance in Hamer and Bena-TsemayWoreda of South Omo Zone, South Western Ethiopia”. Acta Scientific Veterinary Sciences 2.6 (2020): 28-43.

5. Herlocker D. "Rangeland and Resource Development in East Africa”. Portland, Oregon, USA (1999): 203.

6. Norton BW. The nutritive value of tree legumes. In R. C. Gutterdge \& H. M. Shelton (Eds.), Forage tree legumes in tropical agriculture Wallingford, UK: CAB International (1982): 192-201.

7. Skerman PJ., et al. Tropical forage legumes, FAO plant production and protection series, No. 2. Rome: Food and Agricultural Organization of the United Nations (1988).

8. Mokoboki HK., et al. "Chemical composition, in vitro ruminal dry matter degradability and dry matter intake of some selected browse plants". Cogent Food \& Agriculture 5.1 (2019): 20-34.

9. Abule E., et al. "The influence of woody plants and Livestock grazing on grass species composition, yield and soil nutrients in the Middle Awash valley of Ethiopia". Journal of Arid Environments 60.5 (2005): 343-358.

10. BelaynehAnteneh. "Floristic description and Ethno botanical studies of the Natural Vegetation in the Babile Elephant Sanctuary, Ethiopia”. MSc thesis, Addis Ababa University 3 (2006): 2-43.

11. Aderinboye RY., et al. "In vitro gas production and dry matter degradation of four browse leaves using cattle, sheep and goats inocula". Slovakia Journal Animal Science 49.1 (2016): 32-43.

12. Derero A and Kitaw G. "Nutritive values of seven high priority indigenous fodder tree species in pastoral and agro-pastoral areas in Eastern Ethiopia”. Agriculture \& Food Security 7.1 (2018): 1-9.

13. Robles AB., et al. "Role of livestock grazing in sustainable use, natural ness promotion in naturalization of marginal ecosystems of southeastern Spain (Andalusia)". Adv.Agroforestry 6.5 (2008): 211-231.

14. AlemayehuMulugeta and TezeraGetahun. "Socio-economy of pastoral Community in Bena-Tsemay and Hammer Woredas of South Omo Zone, Southern Nations and Nationalities peoples Regional State". Addis Abeba, Ethiopia (2002).

15. Admasu Teferi AbuleErbo and TessemaZewudu. "Livestock-rangeland management practices and community perceptions towards rangeland degradation in South Omo zone of Southern Ethiopia”. Livestock Research for Rural Development 22.5 (2010): 20-25.

16. Zelalem Adane., et al. "Cattle Production System and Breeding Practices in Bena-Tsemay District of SouthOmo, South-Western Ethiopia". International Journal of Agriculture and Biological Sciences 5.3 (2021): 142-159. 
17. Hedberg I and Edwards S. Flora of Ethiopia (3). The National Herbarium, Addis Ababa and Uppsala University, Uppsala (1989).

18. Association of Official Analytical Chemists, Official Methods of Analysis, 15th ed. Association of Official Analytical Chemists. Arlington, VA, USA (1990).

19. Van Soest PJ., et al. "Methods for dietary fiber, neutral detergent fiber, and nonstarch polysaccharides in relation to animal nutrition". J Dairy Sci 74.10 (1991): 3583-3597.

20. Van Soest PJ and Robertson JB. "Methods of dietary fiber, neutral detergent fiber, and non-starch polysaccharides in relation to animal nutrition". J Dairy Sci 74.10 (1987): 3583-3597.

21. Jerenyama $\mathrm{P}$ and Garcia AD. Understanding relative feed value (RFV) and relative forage quality (RFQ). Cooperative Extension Service, South Dakota State University Brookins, SD, USD. South Dakota (2004).

22. Mertens DR. "Physical and chemical characteristics of fiber affecting dairy cow performance". Proceedings of the 2002 Cornell Nutrition Conference for Feed Manufacture, East Syracuse, NY. Ithaca, NY: Cornell University (2002).

23. Fonnesbeck PV., et al. Mathematical models for estimating energy and protein utilization of feedstuffs (1984).

24. Khalil J., et al. "Nutrient composition of Atriplex leaves grown in Saudi Arabia". Rangeland Ecology \& Management/Journal of Range Management Archives 39.2 (1986): 104-107.

25. Kearl LC. Nutrient requirement of ruminants in developing countries. International Feedstuff Institute, Utah Agricultural Experiment Station. Utah State University, London, USA. Kenya, (1982): 381.

26. Statistical Analysis System (2002). SAS/STAT guide for personal computers, version 9.0 editions. SAS Institute Inc.9.0 editions, Cary, NC, USA.

27. Jamarun N., et al. "Chemical composition and rumen fermentation profile of mangrove leaves (Avicennia marina) from West Sumatra, Indonesia". Biodiversitas Journal of Biological Diversity 21.11 (2020).

28. Handayani S. "Kandungan flavonoid kulitbatangdandaunpohon api-api (Avicennia marina (forks.)vierh.) sebagaisenyawaaktif antioksidan". Bogor Agricultural University, Bogor (2013).

29. Ghosh S., et al. "Proximate composition of some mangrove leaves used As alternative fodders in Indian Sunderban Region". Intl J Livest Res 5.11 (2015): 62-65.

30. Gebreselassie N., et al. "Effect of Supplementation with Dried Leaves of Acacia albida, Acacia seyaland their Mixture on Feed Intake and Digestibility of Local Sheep Fed Barley Straw as a Basal Diet”. J Fisheries Livest Prod 2 (2015): 124.

31. Khanal RC and Subba DB. "Nutritional evaluation of leaves from some major fodder trees cultivated in the hills of Nepal". Anim Feed SciTechnol 92.1-2 (2002): 17-32.

32. Megersa E., et al. "Nutritional Characterization of Selected Fodder Species in Abol and Lare Districts of Gambella Region, Ethiopia". J Nutr Food Sci 7 (2017): 581.

33. Bezabih M., et al. "Chemical composition and in vitro total gas and methane production of forage species from the Mid Rift Valley grasslands of Ethiopia”. J BriGrasslSoc 69 (2013): 635-643.

34. Nsahlai IV., et al. "The relationship between gas production and chemical composition of 23 browses of genus Sesbania". Journal of Science and Food Agriculture. 65(1994): 13-20.

35. Luo J., et al. "Maintenance energy requirements of goats: predictions based on observations of heat and recovered energy". Small Ruminant Research 53.7 (2004): 221-230.

36. Pazla R., et al. "Microbial Protein synthesis and fermentability of fermented oil palm fronds by Phanerochaetechrysosporiumin combination with tithonia (Tithoniadiversifolia) and elephant grass (Pennisetumpurpureum)". Pak J Nutr 17.10 (2018): 462470.

37. Orskov ER. Protein nutrition in ruminants. London, UK: Academin Press (1982).

38. Van Soest PJ. "Nutritional Ecology of the Ruminant, Comstock Publishing Associates". A division of Cornell University Press, Ithaca and London (1994).

39. NRC (National Research Council). Nutrient requirements of beef cattle, 7th edn. National Academic Press, Washington (2000): 246. 
40. ARC (Agricultural Research Council). The nutrient requirement of ruminant livestock. Supplement No1. Slough, UK: Common wealth Agricultural Bureaux (1984).

41. Poppidp and Mclennansr. "Protein and energy utilization by ruminants at pasture”. Journal of Animal Science 73 (1995): 278290.

42. Jamarun N and Zain M. Dasarnutrisiruminansia. Jasa Surya Press, Padang (2013).

43. Mtengeti EJ and Mhelela A. Screening of potential indigenous browse species in semi-arid central Tanzani, A case of Gairo division. Livestock Research for Rural Development 18.108 (2006).

44. Belyea RL and Rickets RE. Forages for cattle. New methods of determining energy content and evaluating heat damage. USA: Dept. Anim. Sci. University of Missouri-Columbia (1993).

45. Archimède H., et al. "Effect of regrowth age on intake and digestion of Digitariadecumbens consumed by Black-belly sheep". Anim. Feed Sci. Technol 87.3 (2000): 153-162.

46. ZiblimAbukarilmoro. "Evaluation of the relative feed value of indigenous savanna forage shrub species in Ghana". African Journal of Plant Science 14.2 (2019): 57-64.

47. Shroeder JW. Interpreting Forage Analysis. NDSU Extension service, North Dakota State University, Fargo (1994).

48. Appiah F., et al. "Predicting the Digestibility of Nutrients and Energy Values of 4 Breadfruit Varieties Based on Chemical Analysis". Pakistan Journal of Nutrition 11.4 (2012): 401-405.

49. Kökten K., et al. "Nutritive value of Mediterranean shrubs". Journal of Animal and Plant Science 22.1 (2012): 188-194.

50. Collins M. "Composition and fiber digestion in morphological components of alfalfa-timothy sward". Anim Feed Dci Tech 19 (1988): 135-143.

Volume 1 Issue 1 February 2022

(C) All rights are reserved by Denbela Hidosa and Bizuayehu Ayele. 